\title{
Adapting Integrated High Concentrated PV Modules and Evacuated Tube Collectors to Minimize Building Energy Consumption in Hot Climate
}

\author{
Talal H. Alzanki ${ }^{*}$, Kandil M. Kandil ${ }^{2}$ \\ ${ }^{1}$ Public Authority for Applied Education and Training (PAAET), Electronic Engineering Department, College of Technological \\ Studies, Shuwaikh, Kuwait \\ ${ }^{2}$ Public Authority for Applied Education and Training (PAAET), Applied Sciences Department, College of Technological Studies, \\ Shuwaikh, Kuwait \\ Email: ^th.alzanki@paaet.edu.kw
}

How to cite this paper: Alzanki, T.H. and Kandil, K.M. (2019) Adapting Integrated High Concentrated PV Modules and Evacuated Tube Collectors to Minimize Building Energy Consumption in Hot Climate. Smart Grid and Renewable Energy, 10, 237-256.

https://doi.org/10.4236/sgre.2019.1010015

Received: September 26, 2019

Accepted: October 20, 2019

Published: October 23, 2019

Copyright $\odot 2019$ by author(s) and Scientific Research Publishing Inc. This work is licensed under the Creative Commons Attribution International License (CC BY 4.0).

http://creativecommons.org/licenses/by/4.0/

\begin{abstract}
Energy consumption in buildings is considered a significant portion of gross power dissipation, so a great effort is required to design efficient construction. In severe hot weather conditions as Kuwait, energy required for building cooling and heating results in a huge energy loads and consumption and accordingly high emission rates of carbon dioxide. So, the main purpose of the current work is to convert the existing institutional building to near net-zero energy building (nNZEB) or into a net-zero energy building (NZEB). A combination of integrated high concentrated photovoltaic (HCPV) solar modules and evacuated tube collectors (ETC) are proposed to provide domestic water heating, electricity load as well as cooling consumption of an institutional facility. An equivalent circuit model for single diode is implemented to evaluate triple junction HCPV modules efficiency considering concentration level and temperature effects. A code compatible with TRNSYS subroutines is introduced to optimize evacuated tube collector efficiency. The developed models are validated through comparison with experimental data available from literature. The efficiency of integrated HCPV-ETC unit is optimized by varying the different system parameters. Transient simulation program (TRNSYS) is adapted to determine the performance of various parts of HCPV-ETC system. Furthermore, a theoretical code is introduced to evaluate the environmental effects of the proposed building when integrated with renewable energy systems. The integrated HCPV-ETC fully satisfies the energy required for building lighting and equipment. Utilizing HCPV modules of orientation $25^{\circ}$ accomplishes a minimum energy payback time of about 8 years. Integrated
\end{abstract}


solar absorption chiller provides about $64 \%$ of the annual air conditioning consumption needed for the studied building. The energy payback period (EPT) or solar cooling system is about 18 years which is significantly larger than that corresponding to HCPV due to the extra expenses of solar absorption system. The life cycle savings (LCS) of solar cooling absorption system is approximately $\$ 2400 /$ year. Furthermore, levelized cost of energy of solar absorption cooling is $\$ 0.21 / \mathrm{kWh}$. Hence, the net cost of the solar system after subtracting the $\mathrm{CO}_{2}$ emission cost will be close to the present price of conventional generation in Kuwait (about $\$ 0.17 / \mathrm{kWh}$ ). Finally, the yearly $\mathrm{CO}_{2}$ emission avoided is approximately 543 ton verifying the environmental benefits of integrated HCPV-ETC arrangements in Kuwait.

\section{Keywords}

High Concentrated Photovoltaic, Evacuated Tube Collector, Net-Zero Energy Building, Avoided $\mathrm{CO}_{2}$ Emission

\section{Introduction}

Buildings normally consume a significant portion of the total power utilization. If yearly energy generated from renewable systems is equivalent to the energy needed, the building is called Net-Zero Energy Building (NZEB). On the other hand, when energy generated from renewable systems is a little smaller than energy dissipated, it is identified as nearly Net-Zero Energy Building (nNZEB). Voss et al. [1] introduced a primary solar integrated building. Many research works have implemented audit standards for the buildings and their results showed substantial energy reductions [2] [3] [4]. NZEB attainment is typically determined utilizing different factors such as energy production, net energy costs, and carbon emissions [5]. There are several net-zero energy buildings that designed and assessed all over the world [6] [7].

Rüther et al. [8] investigated the decrease in energy consumption at an international airport in Brazil utilizing integrated photovoltaic modules. Outcomes indicated that integrating these modules would provide the total energy demand for the studied airport. Zhai et al. [9] stated that about $150 \mathrm{~m}^{2}$ of evacuated tube collector in Shanghai, may be utilized to provide the demand of a facility of 460 $\mathrm{m}^{2}$ for cooling and heating. A solar integrated roof is installed by Yin et al. [10] utilizing PV system to minimize energy consumption. The proposed renewable roofing design is proofed to have obvious benefits compared to conventional roofing design. An economic study is carried out [11] to examine environmental impacts of BIPV.

Tsalikis and Martinopoulos [12] examined the integration of solar thermal system and PV modules in a common residential home to investigate the possibility of achieving (NZEB). They indicated that, photovoltaics can provide the required energy consumption of the studied building and the payback period is smaller than seven years. Passive office facility situated Portugal is examined by 
Aeleni et al. [13]. Actual consumption data are employed together with numerical simulations of integrated battery storage system. They concluded that that grid interaction and load matching is enhanced by utilizing the energy supplied by battery storage system. Also, the implementation of this system is economically feasible.

Lopes et al. [14] discussed the effect of load matching in improving net zero energy buildings performance. They made comparison between building and community levels utilizing different options. For a one-year analysis, the community facility is proven to be able to increase energy load by about $21 \%$ and the consumption of the building by about $15 \%$. A dynamic method for accurate comparison of conventional and renewable integrated systems is introduced by Ayadi and Al-Dahidi [15]. Levelized cost of energy technique is employed to compare between renewable energy systems and traditional ones. Results indicated that combined PV and solar thermal systems can attain a significant conventional energy and levelized cost of energy discounts in comparison to traditional energy resources. Rafique et al. [16] investigated the possibility to attain zero energy communities in Pakistan. They adapted simulation software to perform the feasibility study of the suggested PV system. The system feasibility is calculated, and outcomes reveals that suggested photovoltaic integration in rural areas can supply relatively cheaper load demand in comparison to electricity prices.

Karunathilake et al. [17] stated that it is essential to know the most promising energy technology to select community optimal solution for NZEB. In that respect, renewable energy system assessment should incorporate effects of environment. Regarding environmental impacts, it is stated that small hydro and biomass combustion techniques operates better. While, small hydro, gas and biomass combustion operates better considering economic choice. Four buildings for four various weather regions in Arizona is analysed by Heine et al. [18] to evaluate the effect of battery storage on PV system. They showed that because of the discrepancy among peak hours and incident radiation, integrated PV systems can reduce only about $37 \%-44 \%$ of maximum energy load. On the other hand, a maximum net present value can be accomplished by utilizing extra batteries of capacities about one and half times greater to provide yearly maximum load needed with a reasonable grid price.

Sharma et al. [19] stated that utilizing energy storage batteries can decrease the energy required as less load from the grid will be needed in that case. A method to determine the best battery capacity for a common net zero facility with $\mathrm{PV}$ is presented. Optimization predictions showed that with present battery storage prices and electricity tariff in South Australian, the adaption of battery storage energy is feasible. Different strategies to attain zero energy in rural regions in Australia and to determine their effects in zero net energy balance is examined by Miller et al. [20]. Predictions indicate that a combined monitored measurements and simulation software helped residents to attain about 50\% enhancement in the thermal efficiency in addition to solar production of 19,600 
Wh.

Hachem-Vermette et al. [21] investigated a combined residential and commercial/institutional buildings. A hybrid system combined of thermal energy storage and solar thermal collector is installed to examine the effect on the system total efficiency. Outcomes revealed that employing both energy efficiency and photovoltaic modules lead to satisfy about $70 \%$ of the energy demand. A residential house integrated with PV system is analysed by Vieira et al. [22]. The system is modelled utilizing available solar intensity and energy demand of a common residential home in Portugal. It is stated that the system installed was capable to significantly reduce the consumption provided by the electric grid and consequently the electricity bill supplied by the grid.

A single-family building located in Italy installed to represent the weather conditions of Mediterranean is examined by Ascione et al. [23]. Daily energy consumption is calculated to verify the solar generation and battery influence on load requirements. A theoretical code appropriate for the evaluation of energy consumption is utilized to analyze studied building compared to other buildings. Passive building air conditioning is examined by Ascione [24] motivated by the significant increase in space cooling and consequently potential increase in unhealthy effect on surroundings. They concluded that integrated renewable systems should not be considered as the only option for providing energy needed for the building. So, other alternatives as decreasing the air conditioning energy consumption in the building should be considered.

Maurer et al. [25] presented measurements to characterize building integrated solar energy systems components. The significant price reduction attained in the studied buildings are explained, consequently a discussion for the situation of building integrated solar energy in the future is introduced and standards rules are reviewed. Life cycle costs and the environmental impacts of various options are outlined by Sandra et al. [26] to evaluate solar systems potential in increasing energy efficiency. They stated that most of yearly energy required for domestic hot water can be achieved with the integration of renewable systems in addition to the economic feasibility of such systems.

High concentrated photovoltaic (HCPV) modules can be utilized in high energy applications as they can harvest a large amount of energy. Various solar cell techniques [27] [28] [29] are introduced in literature to calculate solar cell efficiency in terms of incident radiation and temperature. To calculate subcells factors, several authors have suggested different techniques to achieve that task adapting various theories. So, a number of methods exists for single diode model [30] [31] and double diode model [32] [33]. However, it should be noted that these techniques evaluate the cell factors at certain circumstances not for all real circumstances which restrict their usage. Utilizing artificial neural networks, Almonacid et al. [34] introduced a method to find correlation among cell maximum energy and different atmospheric factors. Fernandez et al. [35] introduced an elementary relation between open-circuit voltage and solar intensity to anticipate HCPV cell temperatures. 
The different methods mentioned above require direct and regular monitoring of HCPV cells. This certainly involves recording cell electrical factors to determine cell temperature. Also, artificial intelligent methods can be adapted to determine the temperature of HCPV cells from air temperature, direct radiation and wind speed. Nevertheless, these techniques neglect the fraction of radiation which is not transferred to thermal energy. So, these techniques are not reliable for cell temperature evaluation if HCPV cells operate at peak condition since cell temperature may be escalated. Despite the previous published work, the combined influence of temperature and radiation on the efficiency of HCPV cells in hot and harsh climate as that of Kuwait has not been analysed before. This clearly indicates the demand for a dependable technique to accurately calculate the efficiency of HCPV cell through a wide range of climate conditions.

In this work, the building of electronic engineering department at the College of Technological Studies, Kuwait is investigated as an example for present governmental buildings that can be converted to net-zero energy building (NZEB) in severe hot climate weather similar to that of Kuwait. The main objective of this work is to integrate solar energy systems into the proposed building to accomplish NZEB or nNZEB. High concentrated photovoltaic (HCPV) cells are assigned to provide energy required for building lighting and equipment. Also, solar absorption chiller derived by evacuated tube collectors (ETC) are suggested to supply energy requirement for air conditioning. An equivalent circuit for ingle diode is adapted to determine HCPV cells performance in Kuwait taking into account the influence of both concentration ratio and temperature. In addition, a theoretical model is adapted to solve the equations for the different components of ETC. Both HCPV and ETC models are linked with other TRNSYS [36] subroutines to determine the efficiency and the energy output of both HCPV and ETC. Furthermore, the environmental effects of the integrated HCPV-ETC system are evaluated to judge the feasibility of such systems in Kuwait climate.

\section{Theoretical Model of HCPV}

Generally, there are various strategies and processes presented by researchers to analyze the of HCPV cells performance such as the two diodes technique for every subcell, single diode circuit for every subcell, network cell model and lumped diode model. The numerical method adapted to evaluate the efficiency of HCPV modules should precisely take into account the variation of cell power versus incident irradiance, ambient temperature as well as the concentration ratio of a solar cell. In the current work, a model for single diode circuit of triple junctions HCPV cells is utilized to develop a mathematical code to calculate IV characteristics of AZURSPACE [37] triple-junction HCPV cell at various ambient temperatures, intensities and concentration factor. The single diode model offers precise results, in addition it requires fewer empirical parameters to be calculated i.e. less computational time is required compared to the time needed for the two diodes model which necessitates the determination of the empirical 
variables of multi-junction solar cell for every sub-cell. Solar cell technique comprises a source of current which acts as a function of intensity parallel to the diode. Present model can be extended for concentrator modules to account for potential drop resulted because of series resistance. Additionally, diode shunt resistance typically ignored in available techniques is taken into account in current mathematical technique.

Triple junction cell is composed of 3 junctions linked in series. Every connection is described by single diode model. Characteristic equation for each junction is expressed as:

$$
I_{i}=I_{s c, i}-I_{o, i}\left[e^{\frac{q\left(V_{i}+I_{i} R_{s, i}\right)}{n_{i} k_{B} T}}-1\right]-\frac{V_{i}+I_{i} R_{s, i}}{R_{s h, i}}
$$

Each sub cell utilizes 5 parameters: short circuit current $\left(I_{s c}\right)$, series and shunt resistances $R_{s, i}$ and $R_{s h, i}$, saturation current $\left(I_{o, i}\right)$ in addition to diode ideality factor $\left(n_{i}\right)$. T is cell temperature, $k_{B}$ is Boltzmann constant, $V$ is voltages, $q$ is the charge of the electron, $I_{i}$ is the load current; and express junction ( 1 for upper cell, 2 for medium cell and 3 for lower cell). The main parameter impacting the value of $V_{o c}$ is $I_{0}$ (reverse saturation current), that represents deficiency of minority carriers through $p-n$ junction. According to the theory of Shockley diodes $(n=1)$, though $\mathrm{n}$ larger than unity is more adequate to include imperfections created in industrial arrangements. $R_{s}$ is regarded as the main factor aiding to obtain high concentrated cells with improved efficiency. $R_{s h}$ is a result of the leakage current in the $p-n$ junction because of defects. The well-known Maple program is used to perform numerical model calculations. Ghoneim et al. [38] introduced a detailed numerical procedure to analyse and solve Equation (1). The introduced model is examined versus available experimental data provided by the manufacturer of AZURSPACE [37] high concentrated solar cells. The present predicted results agree well with the measurements recorded by AZURSPACE manufacturer.

Grid connected HCPV system presented in Figure 1 is suggested for this work

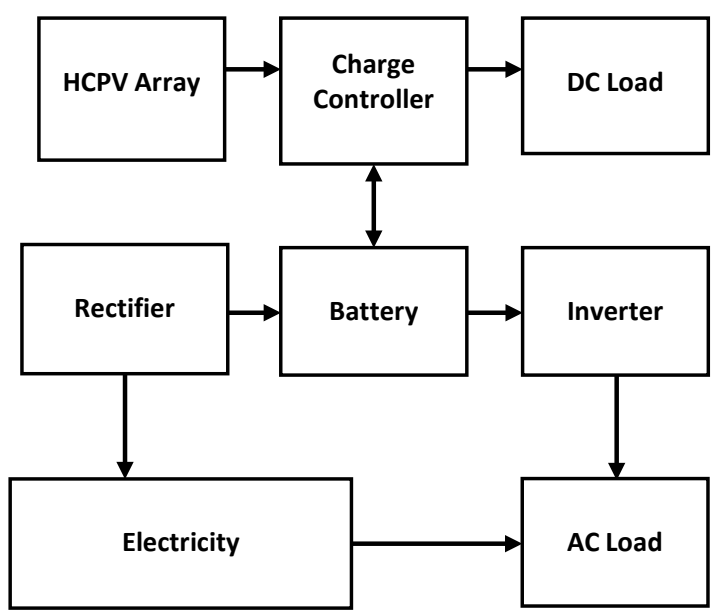

Figure 1. Building integrated high concentrated PV system. 
so HCPV module is not oversized for bad climate. In sunshine times, the batteries are charged by HCPV cells and the required demand is supplied by the batteries. A DC to AC converter is admitted for the conversion of DC generated by HCPV cells to AC needed for household devices. Switches for emergency disconnection are required to assure safety environment.

\section{Theoretical Model of ETC}

The receiver of ETC is composed of U-tube copper contained in a vacuumed tube of glass. A cylindrical aluminum fin circles the copper tube to increase the area of heat transfer between the copper tube and the surface of inside absorber. The working fluid passes to the inlet pipe of the collector to be diffused to the U-tubes, absorbs heat to return to the header tube. The radiation is transmitted from the outer cylindrical glass to the inner glass tube to transfer thermal heat to the absorber fin. The energy converted to thermal energy is transferred by conduction to the copper pipe by the fin and sucked by the fluid. Evacuated tube collector is presumed to be integrated in building to provide building cooling demand. Collector optical efficiency of 0.71 , heat transfer coefficient of 1.42 $\mathrm{W} / \mathrm{m}^{2} \mathrm{~K}$ and a quadratic heat transfer coefficient of $0.03 \mathrm{~W} / \mathrm{m}^{2} \mathrm{~K}^{2}$ is adapted. The model introduced by Ghoneim [39] is adapted to solve the equations for different components of ETC to determine the performance of ETC under Kuwait climate conditions. The developed ETC model uses the energy balance and radiative and convective heat transfer mechanisms within ETC components. It can calculate the collector efficiency, detailed thermal losses from collector as well as collector output energy. The model takes into account the surrounding factors, influence of radiation, properties of materials, fluid characteristics, size of collector and angle of incidence on collector efficiency. The evacuated tube collector component subroutine is then linked with other TRNSYS subroutines to determine the efficiency and the energy output of ETC.

In the present research, evacuated tube optimized factors attained utilizing the numerical code is adapted to construct a proper resized thermal system to generate cooling requirement for the building under study. TRNSYS is adapted to evaluate collector area needed, energy output and solar fraction utilizing using Kuwait weather conditions. The system consists of evacuated tube collector, a single effect absorption chiller, auxiliary heater, controllers and storage tank. The absorption chiller is chosen to create chilled water with outlet temperature $7^{\circ} \mathrm{C}$. Figure 2 presents single-effect lithium bromide water absorption chiller operated by evacuated tube collector. The essential parts of the unit are: generator, absorber, evaporator condenser, and heat exchanger.

Lithium bromide in the absorber is pushed to the generator to be boiled. Cold water passes to the condenser through the absorber. Hot water is provided to air conditioner at a minimum temperature of $87^{\circ} \mathrm{C}$ and a maximum temperature of $93^{\circ} \mathrm{C}$. If storage hot water is less than $87^{\circ} \mathrm{C}$, additional energy is provided to increase it. When stored water is less $77^{\circ} \mathrm{C}$, it is not utilized, instead auxiliary heater satisfies the total demand. Coefficient of performance (COP) represents the 


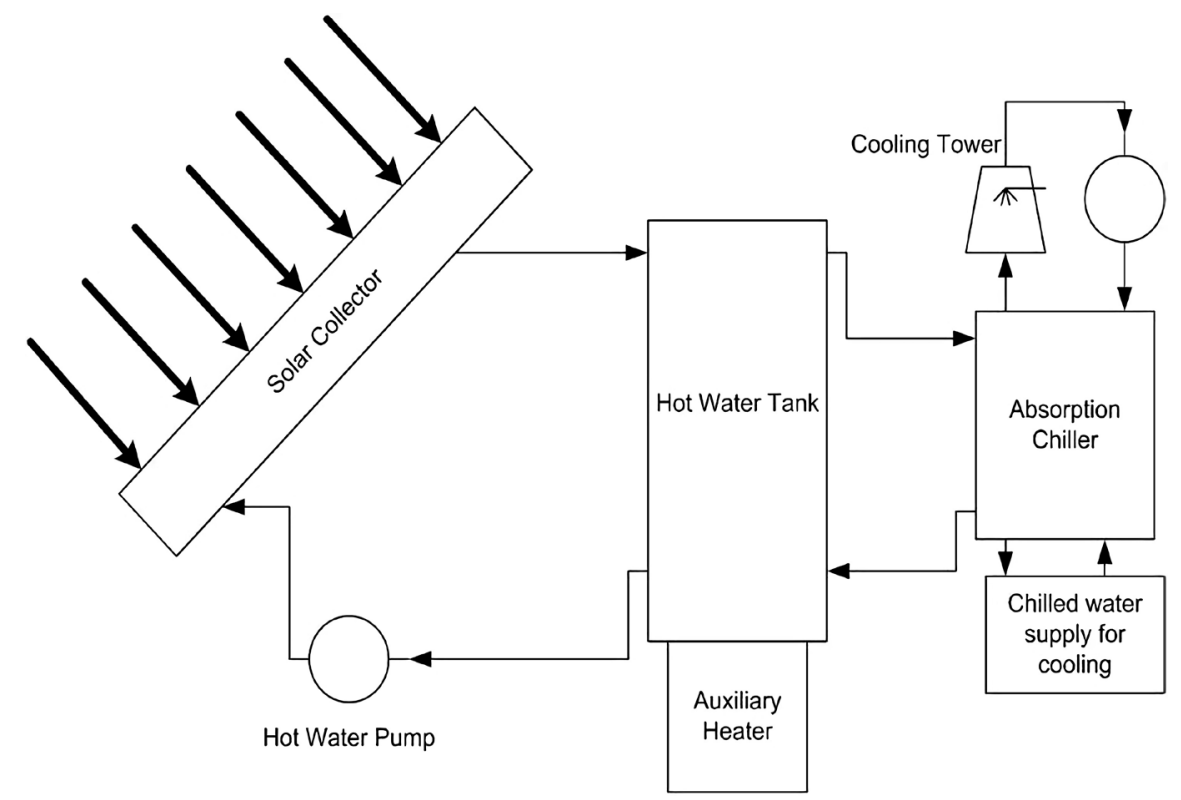

Figure 2. Single effect $\mathrm{LiBr}-\mathrm{H}_{2} \mathrm{O}$ solar absorption unit.

performance of air conditioning systems. The lithium bromide-water have a greater operation condition if the temperature of generator is between 70 to $95^{\circ} \mathrm{C}$ [41] which suggested to be attained by evacuated tube collector. Also, the system has two different configurations; the hot thermal storage and the cold thermal storage.

\section{Building Load}

The proposed building for this study is the Department of Electronic Engineering in the College of Technological Studies, Kuwait. The total floor area of the building is 7020 square meters. Mainly about 600 persons utilize the building from 7 at morning to 6 at evening for 5 days weekly week during study semesters in nonuniform basis. The walls are constructed from cement of $4 \mathrm{~cm}$ followed by $16 \mathrm{~cm}$ thick hollow layers of cement having $7 \mathrm{~cm}$ fixed insulated mass of fiber glass. The building wall composition has an overall heat transfer coefficient of $0.723 \mathrm{~W} / \mathrm{m}^{2} \mathrm{~K}$. Building roof is well insulated and has a $0.196 \mathrm{~W} / \mathrm{m}^{2} \mathrm{~K}$ overall heat transfer coefficient. Building windows are composed of framed aluminum composed from double glazing with thickness $6 \mathrm{~mm}$ having heat transfer coefficient of $4.11 \mathrm{~W} / \mathrm{m}^{2} \mathrm{~K}$.

In dry and hot climate as Kuwait air cooling units are the primary load consumption. Subroutine (Type 56) built in TRNSYS [36] is selected to carryout building simulation. The thermal performance of the building different sections is modelled utilizing this subroutine. This subroutine is employed to characterize the composition of the building utilizing external files. The files can be created utilizing knowledge provided by user through running additional pre-processor code named TRNBuild. Simulation results from running TRNbuild code revealed that air conditioning demand in the building proposed for the present 
work begins in March up to November, with peak in August, July and June, respectively. In present work, air-conditioning system and its components consumes $84 \%$ of overall building energy load. The rest of load is divided among lighting, 9\%, and electronic devices, $7 \%$.

\section{Environmental Impact of HCPV-ETC System}

Carbon dioxide $\left(\mathrm{CO}_{2}\right)$, methane $\left(\mathrm{CH}_{4}\right)$ and nitrous oxide $\left(\mathrm{N}_{2} \mathrm{O}\right)$ are the most harmful gases of conventional sources of energy; but $\mathrm{CO}_{2}$ is regarded as the principal parameter affecting worldwide global warming. That is why the effects of $\mathrm{CO}_{2}$ emissions only are studied in this work. The quantity of carbon emission eliminated through the utilization of solar energy resource is related to conventional resource that is not utilized in addition to the conversion method employed to generate energy. Substituting a plant of larger $\mathrm{CO}_{2}$ emission with a less emitting resource leads to a less $\mathrm{CO}_{2}$ emission. This difference in emitted $\mathrm{CO}_{2}$ is defined as the avoided $\mathrm{CO}_{2}$ emission. The $\mathrm{CO}_{2}$ emission decrease, or $\mathrm{CO}_{2}$ avoided is typically specified as the change among emissions produced by traditional resources and that resulted during manufacturing the solar system through system lifetime which is usually twenty-five years. A simple mathematical expression is utilized to evaluate the avoided $\mathrm{CO}_{2}$ emission accomplished when employing HCPV-ETC system instead of a conventional one. In this work, eliminated $\mathrm{CO}_{2}$ emission $\left(E_{A}\right)$ is primarily the emissions of $\mathrm{CO}_{2}$ produced when utilizing traditional energy resources and is given by:

$$
E_{A}=P_{g} \times F_{E}
$$

where $F_{E}$ is the emission factor of the plant (tonneCO $\mathrm{CO}_{2} / \mathrm{kWh}$ ) and $P_{g}$ is the generated power $(\mathrm{kWh})$.

To calculate $\mathrm{CO}_{2}$ avoided emission because of the utilization of HCPV system, it is necessary to specify the reference electricity system. Frequently this will necessitate identifying a traditional system and the corresponding fuel type. Conversion efficiencies of various fuel types and the standard emission factors are the model input.

\section{Results and Discussions}

\section{Building Integrated Solar Energy}

The aim of the building integrated with high concentrated photovoltaic (HCPV) arrays and evacuated tube collectors is to supply the demand of building energy to transfer it to net-zero energy building (NZEB) or when produced energy is smaller than the required, the building is near net-zero energy building (nNZEB). Building integrated high concentrated photovoltaic (BIHCPV) is employed to supply the load for lighting and devices. Characteristic data of Azurspace HCPV cells are contained in manufacturer's brochure.

Building integrated evacuated tube (BIETC) solar collectors are adapted to provide energy load needed to operate the adsorption chillers for air condition- 
ing load. Evacuated tube collectors in every row are linked in series to achieve useful usage of renewable. This arrangement assures attaining hot water with relatively high temperature to enhance the performance of renewable energy systems. The climate data utilized in this work are monitored and recorded through 8 years. Data information employed are ambient temperature and daily global radiation.

\section{1) Building Integrated HCPV System (BIHCPV)}

Weather measurements used in this study is recorded by a set-up placed at the College of Technological Studies, Kuwait (Latitude 29.5 ${ }^{\circ}$. Data recording contain typical values of hourly global radiation, ambient temperature and direct solar radiation for Kuwait during a period of 8 years in the time from $1^{\text {st }}$ June 2011 until $15^{\text {th }}$ June 2019 . TRNSYS software is used to calculate the performance of the integrated HCPV modules proposed. The time step of simulation in TRNSYS runs is adjusted to hourly simulation. The significant parameters that control HCPV output are ambient temperature, solar intensity, module efficiency and array slope. Characteristic data measured by AZURSPACE cell manufacturer are adapted. Modules area is adjusted to fulfil an adequate portion of the overall roof area available. Subsequently, HCPV array rows can be situated in wide arrangement to reduce the effects of shading. The inverter is assumed to have a fixed efficiency of $92 \%$ [40]. The model developed for HCPV module is invoked into TRNSYS to evaluate annual HCPV output. The information utilized are weather measurements, total utility load as well as building demand.

Figure 3 presents the change of yearly energy generation of Azurspace HCPV with array slope. HCPV orientation is varied from $0^{\circ}$ to $60^{\circ}$ with azimuth angle

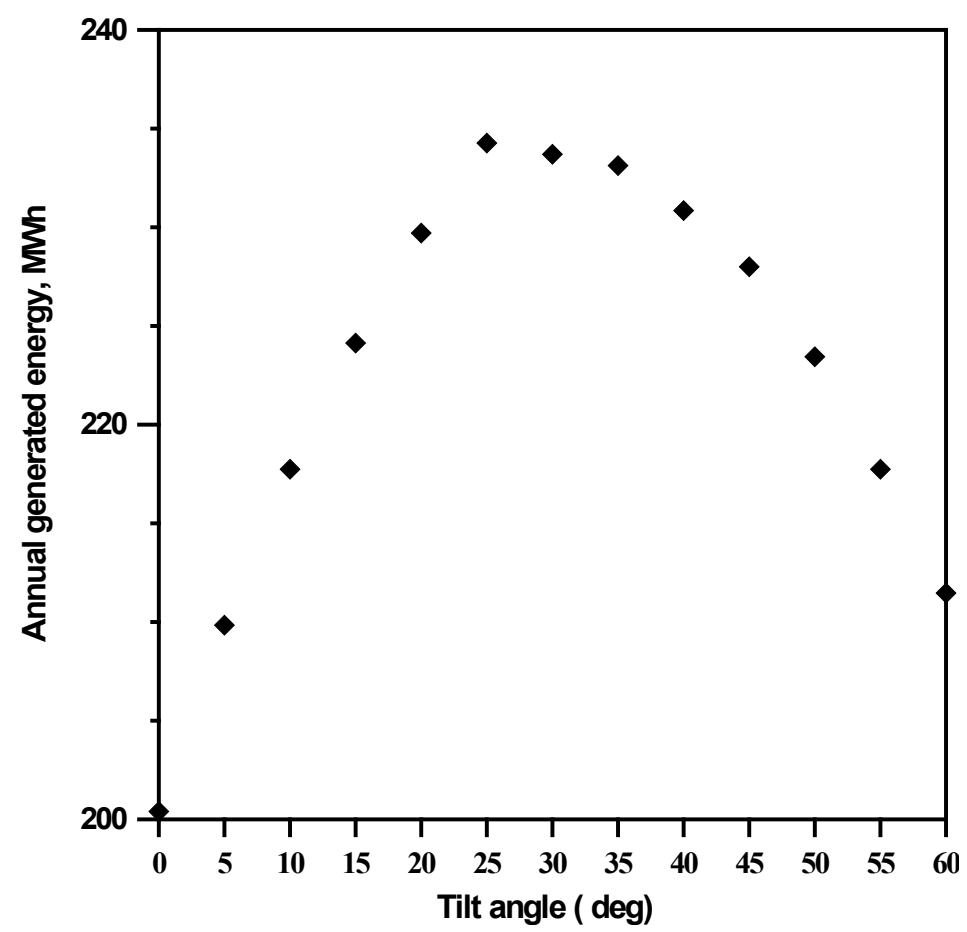

Figure 3. Yearly HCPV energy generation against HCPV slope. 
$0^{\circ}$. Peak energy production from the HCPV modules occurs at slope equal to $25^{\circ}$ (i.e. latitude $-5^{\circ}$ ). Yearly HCPV energy in this condition is about $234 \mathrm{MWh}$. This value is greater than the annual energy required for building lighting and equipment by about $42 \mathrm{MWh}$ which can be exchanged back to the electrical grid. This prediction let us conclude that energy generated from integrated HCPV can provide the entire building lighting load as well as equipment load.

The monthly generated energy of HCPV system is shown in Figure 4 along the monthly consumption energy required for building lighting and equipment. It is obvious that HCPV generated in all months using HCPV system exceeds the building lighting and equipment consumption.

An emission factor of $6.9 \times 10^{-4}$ metric tons $\mathrm{CO}_{2} / \mathrm{kWh}_{\mathrm{e}}$ [40] is employed to determine the annual avoided $\mathrm{CO}_{2}$ emission. Annual avoided $\mathrm{CO}_{2}$ emission change versus HCPV modules slope is illustrated in Figure 5. Figure 5 implies that the $\mathrm{CO}_{2}$ emission eliminated is maximum at an optimum slope angle of $28^{\circ}$ which is near to the latitude of Kuwait $\left(29.5^{\circ}\right)$. The emissions of $\mathrm{CO}_{2}$ avoided at this angle is about 166 tone/year. These predictions clearly verify the environmental impacts of electricity tied HCPV unit in Kuwait.

The precise calculation of $\mathrm{CO}_{2}$ avoided emissions due to utilizing HCPV modules, must consider $\mathrm{CO}_{2}$ emission produced during the manufacturing of $\mathrm{HCPV}$ different components. Generally, the rate of $\mathrm{CO}_{2}$ emissions from $\mathrm{HCPV}$ modules is much smaller than the $\mathrm{CO}_{2}$ emission rate produced from traditional energy resources, therefore it is ignored in this work.

Energy payback times (EPT) can be employed to judge the advantage of BIHCPV systems over traditional energy systems. EPT of BIHCPV system is the time required for the energy delivered through the lifespan of the module is reimbursed by the HCPV energy. The variation of EPT for the proposed BIHCPV system against module slope for zero azimuth angle is illustrated in Figure 6. Utilizing module of orientation of $25^{\circ}$ (i.e. array with tilt of $5^{\circ}$ smaller

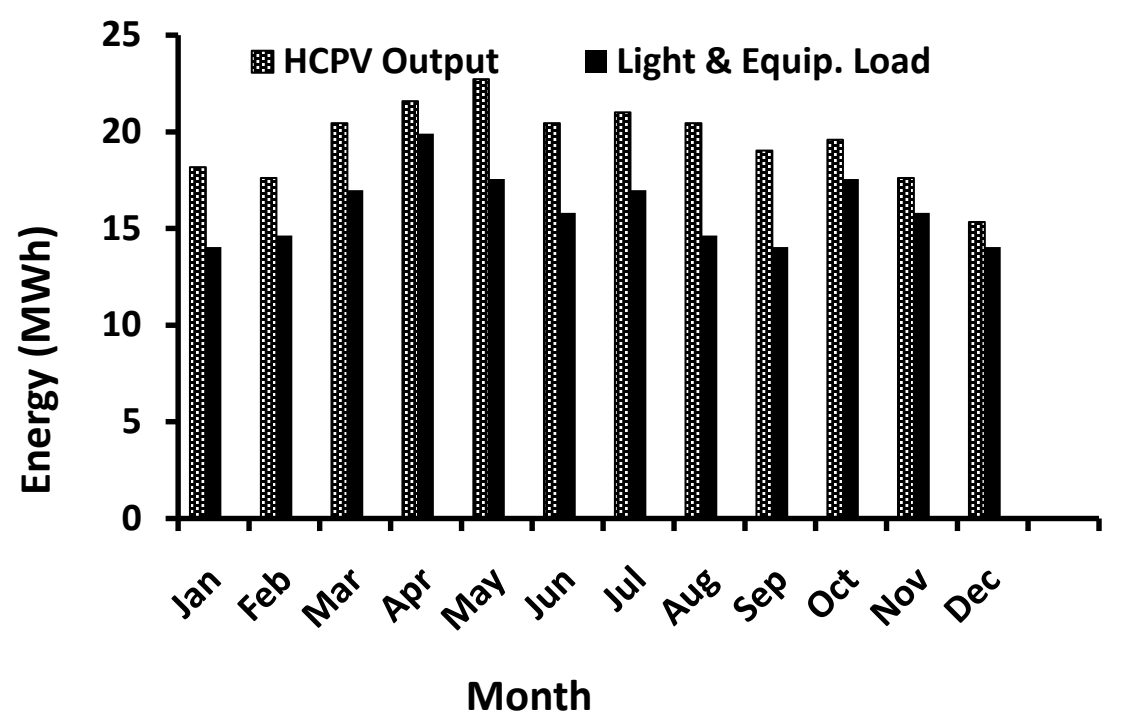

Figure 4. HCPV monthly production along lighting \& equipment consumption. 


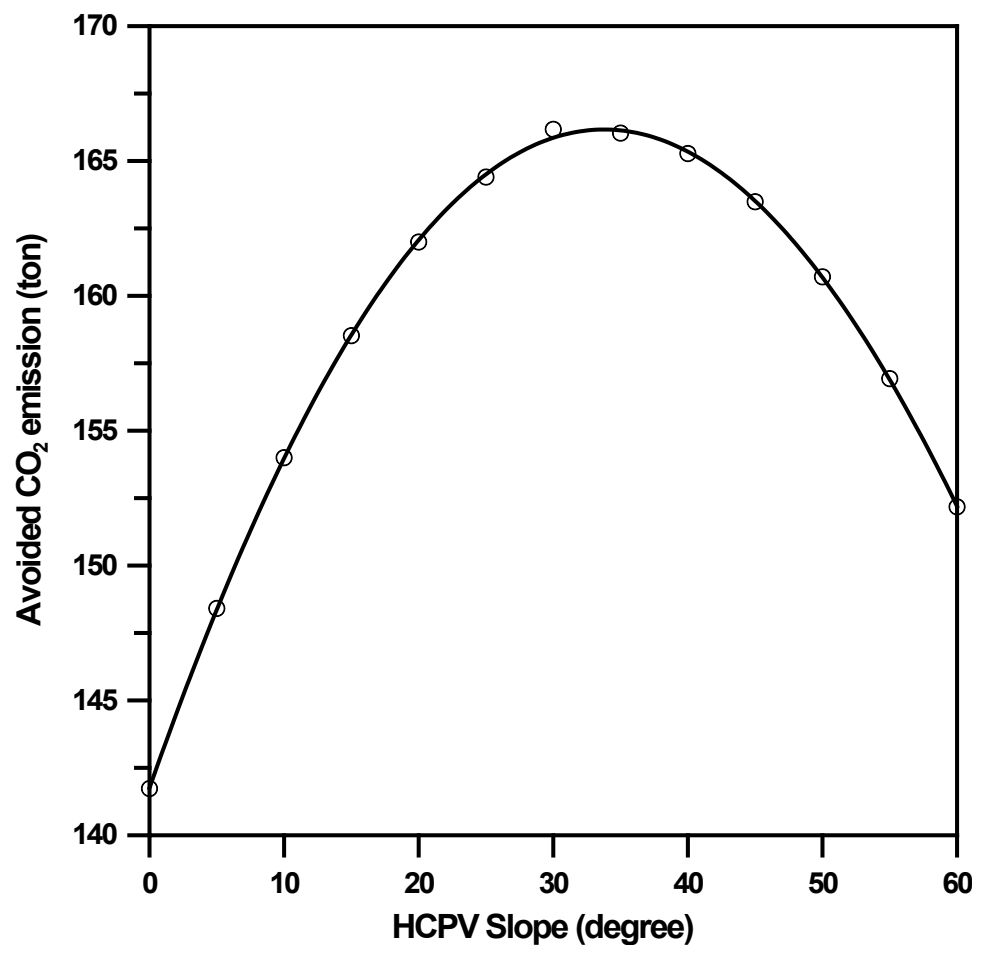

Figure 5. Annual avoided $\mathrm{CO}_{2}$ emission versus $\mathrm{HCPV}$ slope angle.

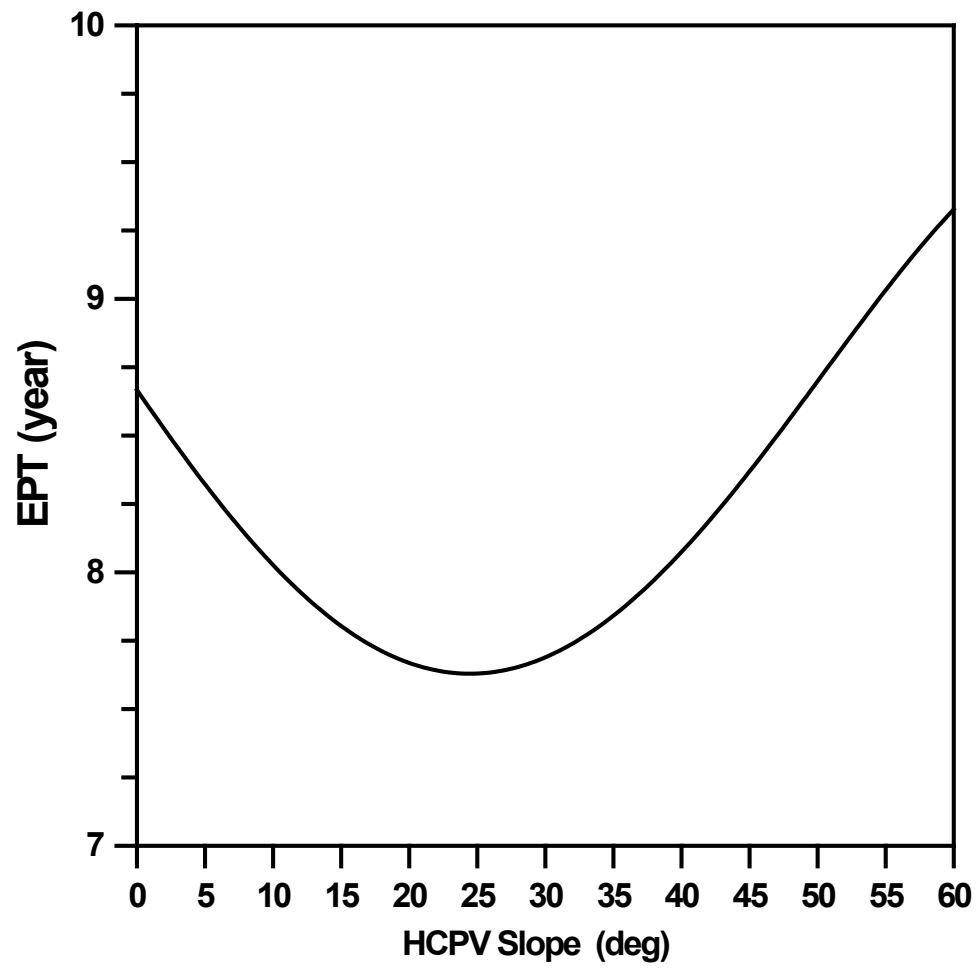

Figure 6. EPT change with slope at constant azimuth angle $\left(\right.$ azimuth $=0^{\circ}$ ).

than Kuwait latitude) accomplishes the minimum EPT which is about 7.7 years. This means that the BIHCPV system can generate free energy after running for 8 years. 


\section{2) Building Integrated Evacuated Tube Collectors (BIETC)}

A code is formulated to resemble the function of a solar lithium bromide absorption system to satisfy building cooling load from March to November. TRNSYS is utilized to connect individual solar cooling parts. Figure 7 illustrates the change of yearly energy generation from ETC for different collector slopes. The orientation of the collector is varied from $0^{\circ}$ to $60^{\circ}$ (i.e. latitude $\pm 30^{\circ}$ ). Also, various angles of azimuth are investigated from $0^{\circ}$ to $40^{\circ}$. As figure shows, the energy generation varies against collector orientation and azimuth angle. It is clear that the peak collector output occurs at tilt angle $25^{\circ}$ (i.e. latitude $+5^{\circ}$ ) and for collector facing south. Consequently, yearly maximum energy generation is obtained utilizing a collector of slope $25^{\circ}$.

The most significant parameter judging the size of solar cooling capacity is solar collector area. Furthermore, collector area has a great influence on solar cooling system feasibility. The predominant parameter controlling solar system economic feasibility is the conventional fuel price. The feasibility analysis in this work utilizes life cycle savings (LCS) technique [41]. LCS over a traditional one is the discrepancy among the decrease in conventional fuel price and the extra costs due to extra expenses of the renewable energy system. So, life cycle saving (LCS) variation against collector area is analyzed to determine solar cooling system feasibility. Furthermore, solar fraction $(F)$ and overall system efficiency $(\eta)$ variation against collector area are examined. Solar fraction is the portion of energy supplied by solar energy and system efficiency is the system output energy divided by input energy. A TRNSYS appropriate code is introduced to calculate the change of system efficiency $(\eta)$, solar fraction $(F)$ and LCS against collector area for the solar cooling system shown in Figure 8. Figure 8 indicates

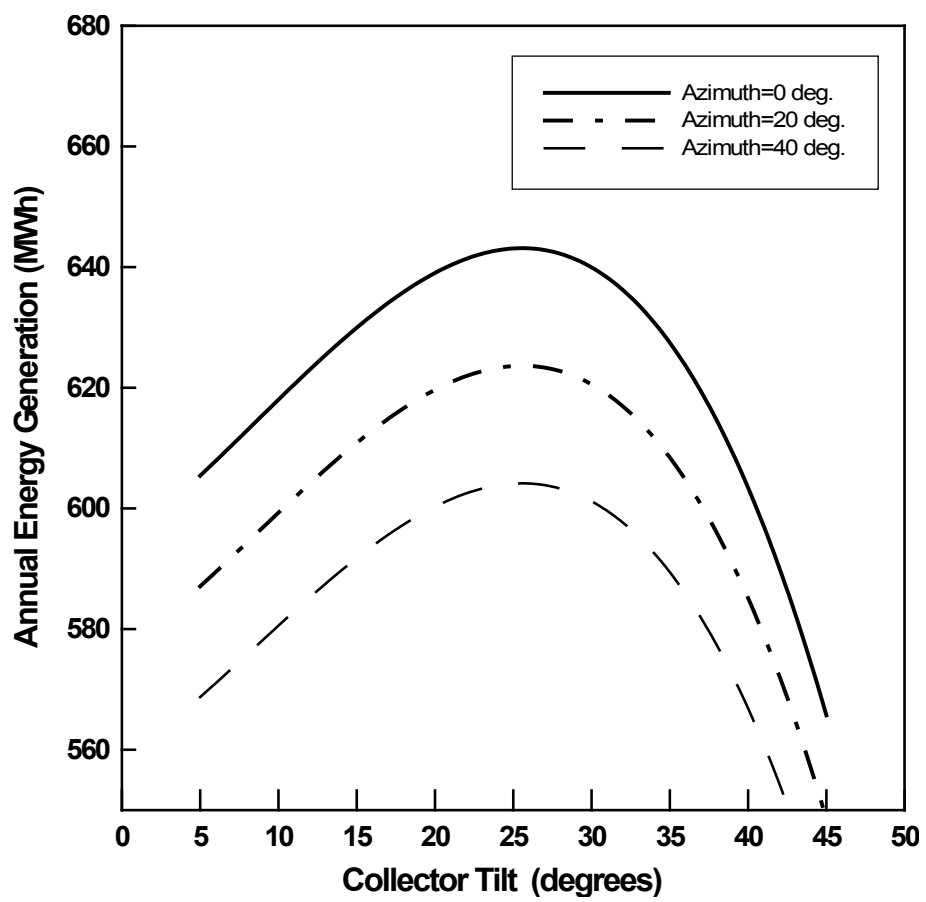

Figure 7. Yearly energy production change with collector tilt. 


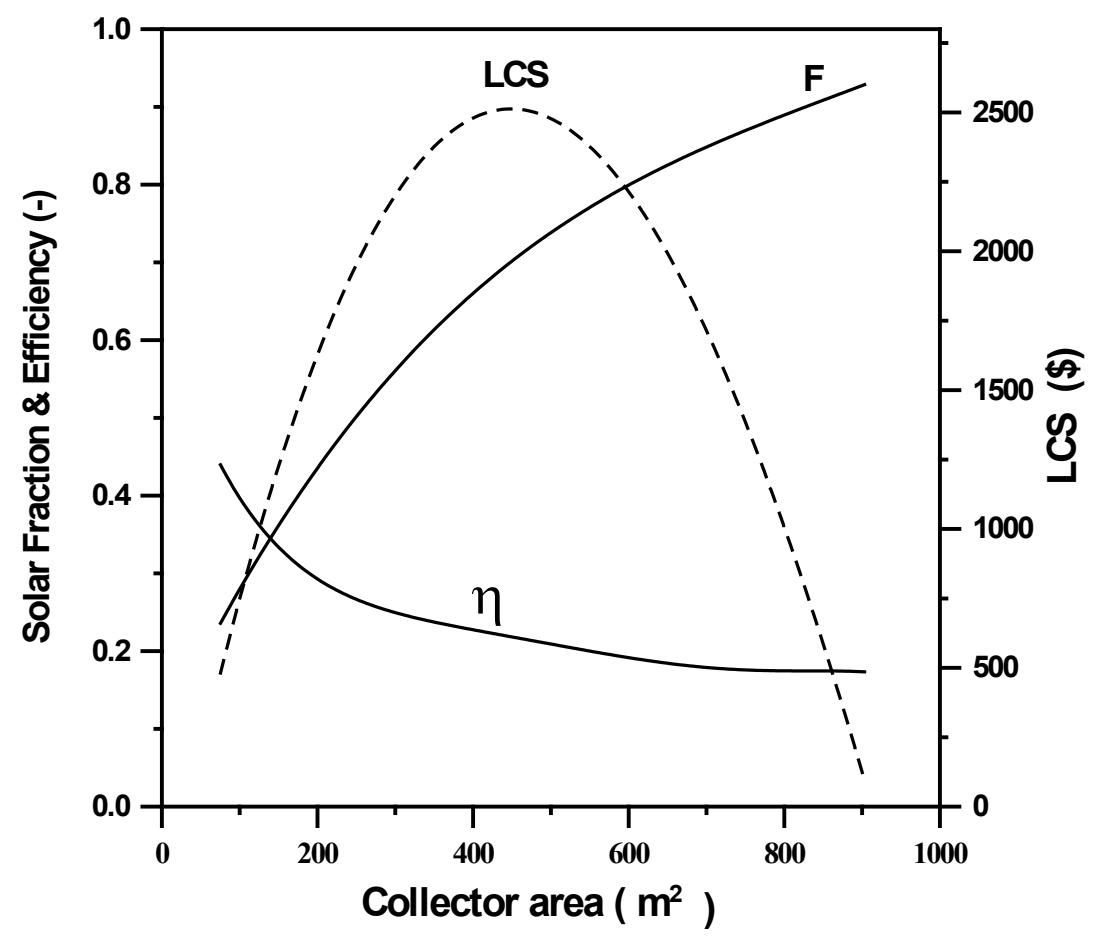

Figure 8. Life cycle savings (LCS), system efficiency $(\eta)$ and solar fraction $(F)$ change with collector area.

that the optimum area at the maximum solar savings is $452 \mathrm{~m}^{2}$ which corresponds to a projection area of $370 \mathrm{~m}^{2}$ allowing enough space to avoid shading effects and to perform operation and maintenance work. As noted, collector optimum area is not corresponding to peak system efficiency or peak solar fraction. The evacuated tube solar fraction provides a satisfactory fraction of the cooling consumption about $64 \%$. The collector efficiency $(\eta)$ has similar behavior to the system efficiency with a little larger value. The coefficient of performance (COP) of the chiller is 0.68 , i.e. in the experimental data range. It is found that an optimum collector area of $25 \mathrm{~m}^{2}$ in addition to storage tank size in the range $1-1.5$ $\mathrm{m}^{3}$ is needed for each ton of refrigeration (TR). So, the available collector area is suitable for absorption cooling system of $18 \mathrm{TR}(63 \mathrm{~kW})$ with COP of about 0.68 for about $20 \mathrm{~m}^{3}$ for hot storage tank and $15 \mathrm{~m}^{3}$ cold storage tank.

Monthly solar cooling energy generated along building cooling load from March to November is calculated and introduced in Table 1. It is found that, solar cooling production surpasses the required load in March and November only, while for other months it provides about $54 \%$ to $72 \%$ of the cooling energy needed. The annual cooling achieved by the solar system is about $640 \mathrm{MWh}$ which represent about $64 \%$ of the annual cooling demand of the building. Thus, an additional efficient conventional air conditioning system is required to compensate for shortage in annual cooling demand of about $360 \mathrm{MWh}$.

Also, at the optimum conditions, annual life cycle savings (LCS) is approximately $\$ 2400$. Solar absorption approximated levelized cost of energy (LCOE) is $\$ 0.21 / \mathrm{kWh}$. So, the price of solar cooling after taking off the price of $\mathrm{CO}_{2}$ emis- 
sion will be very close to present price of generating electricity in Kuwait, which is about $\$ 0.18 / \mathrm{kWh}$. Further, solar energy parts costs have decreased substantially lately and keep reducing which will increase solar cooling economic feasibility greatly.

Yearly avoided $\mathrm{CO}_{2}$ variation along collector tilt angle is shown in Figure 9, as indicated a maximum avoided $\mathrm{CO}_{2}$ emission of 377 tonne/year can be obtained at the optimum tilt angle $25^{\circ}$. Energy payback time (EPT) for solar cooling system

Table 1. Monthly cooling demand and monthly solar cooling capacity.

\begin{tabular}{ccc}
\hline Month & Monthly Solar Cooling Capacity (MWh) & Monthly Cooling Demand (MWh) \\
\hline Mar & 19.7 & 8.5 \\
Apr & 45.4 & 65.9 \\
May & 91.7 & 157.5 \\
Jun & 101.2 & 172.9 \\
July & 113.5 & 193.4 \\
Aug & 87.2 & 125.5 \\
Sept & 81.9 & 151.5 \\
Oct & 74.3 & 114.5 \\
Nov & 25.1 & 10.3 \\
Annually & 640 & 1000 \\
\hline
\end{tabular}

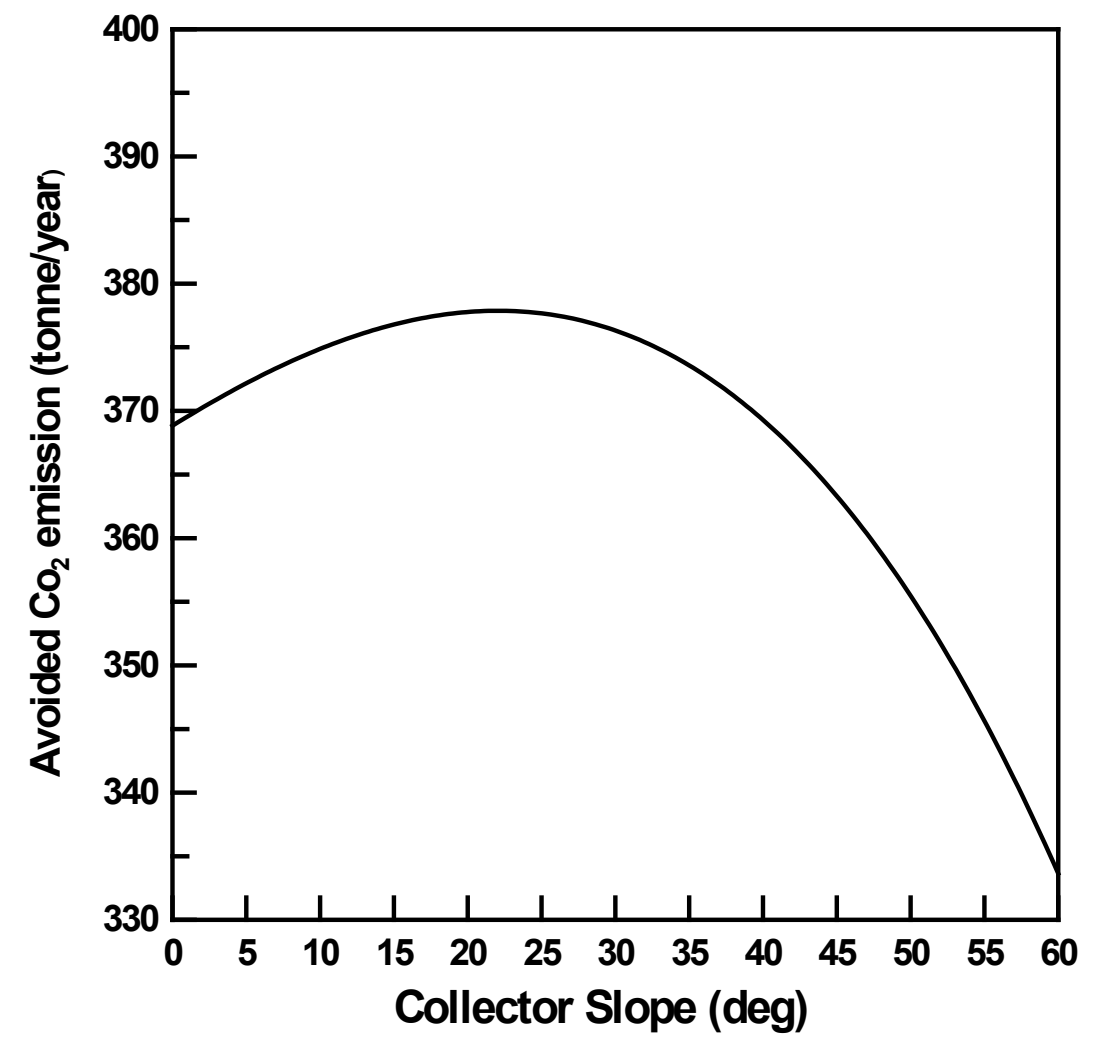

Figure 9. Change of avoided $\mathrm{CO}_{2}$ with collector slope. 
is calculated and it about 18 years which is relatively high in comparison with EPT for HCPV modules due to the higher expenses of solar absorption cooling system. It is interesting to mention that the optimum angle corresponding to minimum payback time (EPT) is the same as the one corresponding to maximum eliminated $\mathrm{CO}_{2}$.

Furthermore, the expenses expected when implementing the Kyoto Protocol, that applying penalties in the case of emissions of greenhouse effect must be included in the prices of fossil fuel sources. Though Kyoto Protocol is not at present applied in Kuwait, nevertheless regarding the use of this protocol will promote the cost effective and environmental impacts of HCPV arrays substantially. Additionally, solar collectors and HCPV modules prices have been reduced considerably lately and keep decreasing greatly which will improve environmental effects and feasibility of solar heating and cooling greatly. Hence, the present outcomes should inspire governments for wide set up of solar heating and cooling systems to reduce energy consumption of conventional fuel and decrease environmental pollution to maintain our community clean and healthy.

\section{Conclusions}

Current work assesses the results of energy generation, using high concentrated photovoltaic (HCPV) modules and evacuated tube collectors (ETC) to drive solar absorption system on an educational building to transform it to a net zero energy building (NZEB) or near net zero energy building (nNZEB). The performance, economic and environmental features of integrated HCPV-ETC building in Kuwait are investigated. Current predictions let us conclude the following:

- Integrating effective HCPV modules and evacuated tube collectors can convert public buildings in Kuwait to nearly NZEB.

- Integrating HCPV modules with slope of $25^{\circ}$ (i.e. Kuwait latitude $-5^{\circ}$ ) into the building generates about $192 \mathrm{MWh}$ which surpasses lighting and equipment energy demand of the building.

- Utilizing HCPV modules of orientation of $25^{\circ}$ (i.e. array with tilt of $5^{\circ}$ smaller than Kuwait latitude) accomplishes a minimum EPT in about 7.7 years. So, BIHCPV system can generate free energy after running for 8 years.

- Evacuated tube collectors of area $466 \mathrm{~m}^{2}$, with tilt of $25^{\circ}$ for collector due south can provide $64 \%$ of air-conditioning requirement in the building which is considered a significant fraction of the building cooling demand.

- Approximately $360 \mathrm{MWh}$ of the total building demand should be supplied by conventional energy sources.

- Payback period for solar cooling system is about 18 years which is relatively high due to the higher expenses of solar absorption system.

- Annually LCS for solar cooling absorption system is about $\$ 2400$ for the optimum conditions.

- LCOE of solar absorption cooling is $\$ 0.21 / \mathrm{kWh}$. Hence, the net price of solar system after subtracting the $\mathrm{CO}_{2}$ emission cost will be close to the present 
price of generating electricity in Kuwait, which is about $\$ 0.18 / \mathrm{kWh}$.

- Annual avoided $\mathrm{CO}_{2}$ of 543 ton can be obtained by integrating HCPV-ETC into the building.

- HCPV module prices are anticipated to be reduced significantly in near future. Furthermore, HCPV cells efficiency continue to be enhanced, so HCPV systems will be cost effective.

- Present results should inspire Kuwait government for extensive installment of renewable energy applications to preserve our environment clean and healthy.

\section{Acknowledgements}

Authors would like to thank The Public Authority for Applied Education and Training (PAAET), Kuwait for supporting this work through the project No. (TS-17-07).

\section{Conflicts of Interest}

The authors declare no conflicts of interest regarding the publication of this paper.

\section{References}

[1] Voss, K., Goetzberger, A., Bopp, G., Haberle, A., Heinzel, A. and Lehmberg, H. (1996) The Self-Sufficient Solar House in Freiburg-Results of 3 Years of Operation. Solar Energy, 58, 17-23. https://doi.org/10.1016/0038-092X(96)00046-1

[2] Marszal, A.J., Heiselberg, P., Bourrelle, P., Musall, E., Voss, K., Sartori, I. and Napolitano, A. (2011) Zero Energy Building-A Review of Definitions and Calculation Methodologies. Energy and Buildings, 43, 971-979.

https://doi.org/10.1016/j.enbuild.2010.12.022

[3] Rahman, M.M., Rasul, M.G. and Khan, M.M.K. (2010) Energy Conservation Measures in an Institutional Building in Sub-Tropical Climate in Australia. Applied Energy, 87, 2994-3004. https://doi.org/10.1016/j.apenergy.2010.04.005

[4] Oliver, M. and Jackson, T. (2001) Energy and Economic Evaluation of Building Integrated Photovoltaics. Energy, 26, 431-439.

https://doi.org/10.1016/S0360-5442(01)00009-3

[5] Tsoutsos, T., Aloumpi, E., Gkouskos, Z. and Karagiorgas, M. (2010) Design of a Solar Absorption Cooling System in a Greek Hospital. Energy and Buildings, 42, 265-272. https://doi.org/10.1016/j.enbuild.2009.09.002

[6] Reijenga, T.H. (2000) Energy Efficient and Zero-Energy Building in the Netherlands. In: International Workshop on Energy Efficiency in Buildings in China for the 21 st Century, CBEEA, Beijing.

[7] Gilijamse, W. (1995) Zero-Energy Houses in the Netherlands. Proceedings of Building Simulation' 95, Madison, WI, 14-16 August 1995, 276-283.

[8] Rüther, R. and Braun, P. (2009) Energetic Contribution Potential of Building-Integrated Photovoltaics on Airports in Warm Climates. Solar Energy, 83, 1923-1931. https://doi.org/10.1016/j.solener.2009.07.014

[9] Zhai, X.Q., Wang, R.Z., Dai, Y.J. and Wu, J.Y. (2008) Experience on Integration of Solar Thermal Technologies with Green Buildings. Renewable Energy, 33, 1904- 
1910. https://doi.org/10.1016/j.renene.2007.09.027

[10] Yin, H.M., Yang, D.J. Kelly, G. and Garant, J. (2013) Design and Performance of a Novel Building Integrated PV/Thermal System for Energy Efficiency of Buildings. Solar Energy, 87, 184-195. https://doi.org/10.1016/j.solener.2012.10.022

[11] Keoleian, A. and Lewis, G. (2003) Modeling the Life Cycle Energy and Environmental Performance of Amorphous Silicon BIPV Roofing in the US. Renewable Energy, 28, 271-293. https://doi.org/10.1016/S0960-1481(02)00022-8

[12] Tsalikis, G. and Martinopoulos, G. (2015) Solar Energy Systems Potential for Nearly Net Zero Energy Residential Buildings. Solar Energy, 115, 743-756. https://doi.org/10.1016/j.solener.2015.03.037

[13] Aelenei, D., Lopes, R., Aelenei, L. and Gonçalves, H. (2019) Investigating the Potential for Energy Flexibility in an Office Building with a Vertical BIPV and a PV Roof System. Renewable Energy, 137, 189-197. https://doi.org/10.1016/j.renene.2018.07.140

[14] Lopes, R., Martins, J., Aelenei, D. and Lima, C. (2016) A Cooperative Net Zero Energy Community to Improve Load Matching. Renewable Energy, 93, 1-13. https://doi.org/10.1016/j.renene.2016.02.044

[15] Ayadi, O. and Al-Dahidi, S. (2019) Comparison of Solar Thermal and Solar Electric Space Heating and Cooling Systems for Buildings in Different Climatic Regions. Solar Energy, 188, 545-560. https://doi.org/10.1016/j.solener.2019.06.033

[16] Rafique, M., Rehman, S. and Alhems, M. (2018) Developing Zero Energy and Sustainable Villages-A Case Study for Communities of the Future. Renewable Energy, 127, 565-574. https://doi.org/10.1016/j.renene.2018.04.087

[17] Karunathilake, H., Hewage, K., Merida, W. and Sadiq, R. (2019) Renewable Energy Selection for Net-Zero Energy Communities: Life Cycle-Based Decision Making under Uncertainty. Renewable Energy, 130, 558-573.

https://doi.org/10.1016/j.renene.2018.06.086

[18] Heine, K., Thatte, A. and Tabares-Velasco, P. (2019) A Simulation Approach to Sizing Batteries for Integration with Net-Zero Energy Residential Buildings. Renewable Energy, 139, 176-185. https://doi.org/10.1016/j.renene.2019.02.033

[19] Sharma, V., Haque, M. and Aziz, S. (2019) Energy Cost Minimization for Net Zero Energy Homes through Optimal Sizing of Battery Storage System. Renewable Energy, 141, 278-286. https://doi.org/10.1016/j.renene.2019.03.144

[20] Miller, W., Liu, L., Amin, Z. and Gray, M. (2018) Involving Occupants in Net-ZeroEnergy Solar Housing Retrofits: An Australian Sub-Tropical Case Study. Solar Energy, 159, 390-404. https://doi.org/10.1016/j.solener.2017.10.008

[21] Hachem-Vermette, C., Guarino, F., Rocca, V. and Cellura, M. (2019) Towards Achieving Net-Zero Energy Communities: Investigation of Design Strategies and Seasonal Solar Collection and Storage Net-Zero. Solar Energy, 192, 169-185. https://doi.org/10.1016/j.solener.2018.07.024

[22] Vieira, F., Moura, P. and Almeida, A. (2017) Energy Storage System for Self-Consumption of Photovoltaic Energy in Residential Zero Energy Buildings. Solar Ener$g y$, 103, 308-320. https://doi.org/10.1016/j.renene.2016.11.048

[23] Ascione, F., Borrelli, M., DeMasi, F., Rossi, F. and Vanoli, G. (2019) A Framework for NZEB Design in Mediterranean Climate: Design, Building and Set-up Monitoring of a Lab-Small Villa. Solar Energy, 184, 11-29. https://doi.org/10.1016/j.solener.2019.03.083

[24] Ascione, F. (2017) Energy Conservation and Renewable Technologies for Buildings 
to Face the Impact of the Climate Change and Minimize the Use of Cooling. Solar Energy, 154, 34-100. https://doi.org/10.1016/j.solener.2017.01.022

[25] Maurer, C., Cappel, C. and Kuhn, T. (2017) Progress in Building-Integrated Solar Thermal Systems. Solar Energy, 154, 158-186. https://doi.org/10.1016/j.solener.2017.05.065

[26] Sandra, R., Manuela, M. and Almeida, G. (2019) Environmental and Cost Life Cycle Analysis of the Impact of Using Solar Systems in Energy Renovation of Southern European Single-Family Buildings. Renewable Energy, 137, 82-92. https://doi.org/10.1016/j.renene.2018.04.036

[27] Liu, C.Y., Yuan, S., Dong, J.R. and Chua, S.J. (2004) Temperature Dependence of Photo-Luminescence Intensity from AlGaInP/GaInP Multi-Quantum Well Laser Structure. Journal of Crystal Growth, 268, 426-431. https://doi.org/10.1016/j.jcrysgro.2004.04.067

[28] Nelson, J. (2003) The Physics of Solar Cells. Imperial College Press, London.

[29] Newman, F., Aiken, D., Patel, P., Chumney, D., Aeby, I., Hoffman, R. and Sharps, O. (2009) Optimization of Inverted Metamorphic Multi-Junction Solar Cells for Field Deployed Concentrating PV Systems. 34th IEEE Photovoltaic Specialists Conference (PVSC), Philadelphia, PA, 7-12 June 2009, 1611-1616. https://doi.org/10.1109/PVSC.2009.5411385

[30] Segev, G., Mittelman, G. and Kribus, A. (2012) Equivalent Circuit Models for Triple-Junction Concentrator Solar Cells. Solar Energy Materials and Solar Cells, 98, 57-65. https://doi.org/10.1016/j.solmat.2011.10.013

[31] Ben Or, A. and Appelbaum, J. (2013) Estimation of Multi-Junction Solar Cell Parameters. Progress in Photovoltaics. Research and Applications, 21, 713-723. https://doi.org/10.1002/pip.2158

[32] Nishioka, K., Takamoto, T., Agui, T., Kaneiwa, M., Uraoka, Y. and Fuyuki, T. (2004) Evaluation of InGaP/InGaAs/Ge Triple-Junction Solar Cell under Concentrated Light by Simulation Program with Integrated Circuit Emphasis. Japan Journal of Applied Physics, 43, 882-890. https://doi.org/10.1143/JJAP.43.882

[33] Nishioka, K., Sueto, T., Uchina, M. and Ota, Y. (2010) Detailed Analysis of Temperature Characteristics of an InGaP/InGaAs/Ge Triple-Junction Solar Cell. Journal of Electronic Materials, 39, 704-708. https://doi.org/10.1007/s11664-010-1171-y

[34] Almonacid, F., Fernandez, E., Perez-Higueras, P., Rodrigo, P. and Rus Casas, C. (2013) Estimating the Maximum Power of a High Concentrator Photovoltaic (HCPV) Module Using an Artificial Neural Network. Energy, 53, 165-172. https://doi.org/10.1016/j.energy.2013.02.024

[35] Fernandez, E., Almonacid, F., Rodrigo, P. and Perez-Higueras, P. (2014) Calculation of the Cell Temperature of a High Concentrator Photovoltaic Module: A Study and Comparison of Different Methods. Solar Energy Materials \& Solar Cells, 121, 144-151. https://doi.org/10.1016/j.solmat.2013.11.009

[36] Klein, S.A., et al. (2018) TRNSYS, A Transient Simulation Program. Version 17, University of Wisconsin-Madison, Madison, WI.

[37] Azurspace Solar Power GmbH (2019) https://www.azurspace.com

[38] Ghoneim, A.A., Kandil, M.K., Alzanki, T.H. and Alenezi, M.R. (2018) Performance Analysis of High Concentrated Multi-Junction Solar Cells in Hot Climate. International Journal of Sustainable Energy, 37, 294-310. https://doi.org/10.1080/14786451.2016.1270284

[39] Ghoneim, A.A. (2018) Performance Optimization of Evacuated Tube Collector for 
Solar Cooling of a House in Hot Climate. International Journal of Sustainable Energy, 37, 193-208. https://doi.org/10.1080/14786451.2016.1256886

[40] Duffie, J.A. and Beckman, W.A. (2013) Solar Engineering of Thermal Processes. 4th Edition, John Wiley \& Sons Inc., New York. https://doi.org/10.1002/9781118671603

[41] EPA United States Environmental Protection Agency (2011) Calculations and References; $\mathrm{CO}_{2}$ Emission Factor, Clean Energy. 